\title{
THE FORMATION OF FOREIGN LANGUAGE COMPETENCE OF ENGINEERING STUDENTS BY MEANS OF MULTIMEDIA
}

\author{
Iryna Stavytska \\ National Technical University of Ukraine “Igor Sikorsky Kyiv Polytechnic Institute”, Kyiv, Ukraine \\ iryna_stavytska@ukr.net
}

The research is devoted to the scientific substantiation of pedagogical conditions and experimental verification of model of the formation of foreign language competence of students in Mechanical Engineering. The author defines the concept of "foreign language competence" as a dynamic combination of knowledge and practical skills. The term determines the ability of individuals to use a foreign language in professional, scientific activities and in social communication successfully. The research represents the model of the formation of foreign language competence of engineering students by multimedia that includes criteria (motivation, reflexive, cognitive activity, practical and technological), and levels of performance (high, sufficient, average, low). The pedagogical conditions of formation of foreign language competence comprise the interrelationship of the humanities and professional disciplines in the training of students, the vocational and academic orientation of foreign language learning, a combination of multimedia with traditional forms of studying, inten sification of students' independent work by means of distance learning. The formative experiment reveals positive changes in the levels of forming foreign language competence of the experimental group compared with the control one. The obtained results confirm the correctness of the hypothesis, according to which the effectiveness of professional training of engineering students enhances if the formation of foreign language competence is carried out with the use of multimedia and under certain pedagogical conditions.

Keywords: competence; foreign language competence; multimedia; Master's student; Mechanical Engineering, speciality; distance course.

\section{Introduction}

The modern development of new technologies, integration of Ukraine into the education area, accelerated information development of society, informatization of education lead to new requirements for training future industrial engineering specialists. Highly qualified engineers should have adequate professional knowledge of foreign languages and new technologies. In modern society, knowledge of foreign languages is a factor of increasing the competitiveness of professionals.

The analysis of scientific sources indicates that there are different views on the definition of "competence". The Project Tuning Educational Structures was started to establish the connection between learning outcomes, competences and credit system ECTS. According to the project, competences represent a dynamic combination of cognitive and metacognitive skills, knowledge and understanding, interpersonal, intellectual and practical skills, and ethical values (Tuning Project, 2008). Competences can be distinguished in subject-specific and generic ones.

The term "competence" means the proven ability to use knowledge, skills and personal, social and/or methodological abilities, in work or study situations and in professional and personal development (The European Qualifications Framework for Lifelong Learning, 2008).

The Law of Ukraine "On Higher Education" determines competence as a dynamic combination of knowledge, skills, ways of thinking, professional, philosophical and civic qualities, moral and ethical values (The Law of Ukraine "On Higher Education", 2014).

A young person obtains competence not only in the studying of the subject or a group of subjects but also by means of non-formal education, due to the influence of environment and so on (Honcharenko, 2011). Professionally oriented foreign language training is treated as an integral component of the professional training of future specialists (Feschuk, 2016, p. 47).

The following factors are related to higher foreign language competence: earlier studying of a language, practical experience, informal language learning opportunities (Ashton, 2014, p. 14).

The purpose of the article is to study the formation of foreign language competence of engineering students by means of multimedia. The following objectives are stated:

- to analyse scientific and methodological literature on the formation of foreign language competence;

- to clarify the essence of the concept of "foreign language competence";

- to improve the testing methodology of formation of foreign language competence of Master's students in Mechanical Engineering by means of multimedia and define the criteria and indicators;

- to check the experimental model of the formation of foreign language competence of Master's students in Mechanical Engineering by means of multimedia;

- to develop distance learning courses using multimedia for students of engineering specialities. 
The hypothesis of the research is that the effectiveness of professional training of engineering students enhances if the formation of foreign language competence is carried out with the use of multimedia and under certain pedagogical conditions.

There are different views as to what is required to be formed at the foreign language lessons. Scientists study different concepts of "foreign language competence", "professional foreign language competence", "professional foreign language communicative competence", "foreign language communicative competence" and "foreign language professional competence".

On the basis of the analysis of the concept and structure of foreign language competence of professionals in different areas, it is established that in modern pedagogical literature there is no common understanding of the essence of foreign language competence. "Foreign language competence" is a complex and multifaceted scientific concept. Summarising various scientific theoretical approaches, we formulate "foreign language competence" as a dynamic combination of knowledge, practical skills. Foreign language competence determines the ability of individuals to use a foreign language in professional, scientific activities and in social communication successfully (Stavytska, 2015).

\section{Methods}

To achieve the purpose of the research the complex methods are used:

1. Analysis, synthesis, systematisation and generalisation of scientific data contained in pedagogical, philosophical and methodological literature, legal acts in the field of higher education to determine the state of the research problem and identify the pedagogical conditions of multimedia application for foreign language training of engineering students;

2. Tests, interviews, surveys of students and teachers for primary empirical research;

3. Modelling - for the development of the model of formation of foreign language competence;

4. Pedagogical experiment (ascertaining and formative) to test the effectiveness of the model of the formation of foreign language competence;

5. Methods of mathematical statistics (Pearson criterion and criterion of Cramer-Welch) for quantitative and qualitative analysis of the results of scientific research.

The objectives of the experimental work are:

- to check the efficiency of the criteria of the formation of foreign language competence;

- to determine the effectiveness of the pedagogical conditions for developing foreign language competence of Master's students in Mechanical Engineering;

- to check the efficiency of using multimedia technologies in foreign language teaching;

- to analyse the effectiveness of the proposed methods of formation of foreign language competence by means of multimedia.

In our research, the model of the formation of foreign language competence of engineering students by multimedia means is tested. As shown in Figure 1 the main components of the model are the target (objective, task), theoretical (approaches, principles, pedagogical conditions), organisational and procedural, effective and evaluative (criteria, levels, result). The peculiarity of the model is the usage of multimedia system Moodle for foreign language training of engineering students.

305 students and 68 teachers of the National Technical University of Ukraine "Igor Sikorsky Kyiv Polytechnic Institute" took part in experimental work. 93 students took part in the formative experiment. 48 students created the experimental group (EG), 45 students were in the control group (CG). The control group was taught in a traditional way; practical and independent work of students was carried out without the systematic use of media in education.

Within ascertaining experiment the following methods were used: questionnaires, tests, individual and group interviews, teacher observations, quantitative and qualitative methods of processing the data. At this stage, we studied the motivation for learning a foreign language (the method of G. Kazantseva "The attitude to learning academic subjects" (Holovei \& Rybalko, 2002)), the ability to analyse and evaluate students' activities (self-assessment sheets (Stavytska, 2015)) and the focus on a certain type of engineering (the method of O. Hodlinik (Ilin, 2003, p.460)).

The diagnostic method of forming foreign language competence of Masters of engineering specialities is improved by using self-developed questionnaires. As shown in Table 1 the criteria (motivation, reflexive, cognitive activity, practical and technological), and levels of performance (high, sufficient, average, low) are developed. 


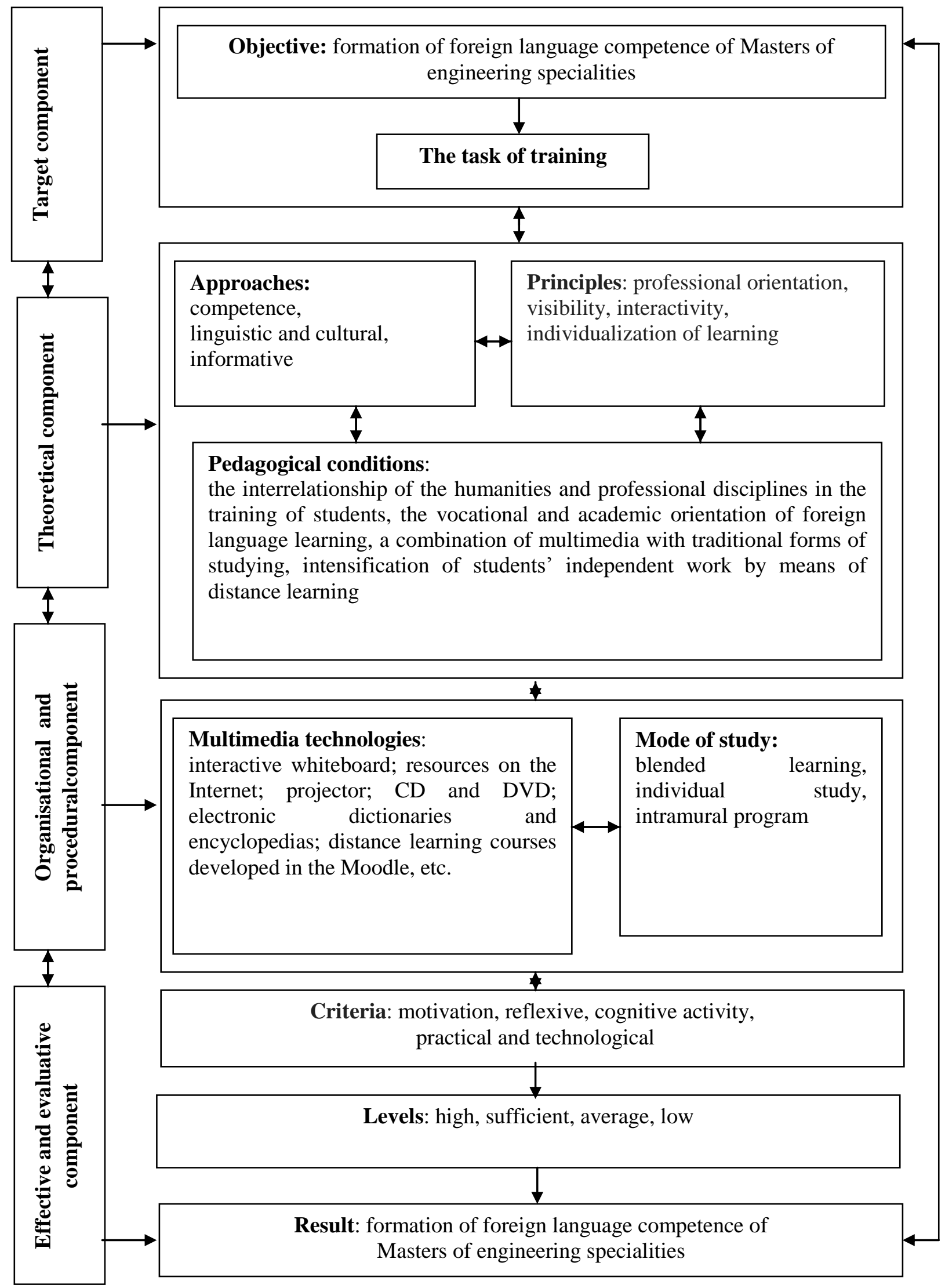

Figure 1. The model of formation of foreign language competence of Master's students in Mechanical Engineering by means of multimedia 
Table 1

The value of criteria and indicators of formation of foreign language competence of Masters of engineering specialities with the use of multimedia

\begin{tabular}{|l|l|}
\hline Criteria & \multicolumn{1}{c|}{ Indicators } \\
\hline Motivation & $\begin{array}{l}\text { The importance of foreign language training and social communication; } \\
\text { interest in learning a foreign language; } \\
\text { assess the feasibility to study professionally and scientifically oriented } \\
\text { foreign language based on individual abilities. }\end{array}$ \\
\hline Reflexive & $\begin{array}{l}\text { The ability to self-esteem; } \\
\text { ability to analyse and evaluate your knowledge of a foreign language; } \\
\text { capacity for self-study of foreign languages. }\end{array}$ \\
\hline Cognitive activity & $\begin{array}{l}\text { Reading and translation of authentic texts in the speciality; } \\
\text { discussion of topics of professional issues; } \\
\text { speech perception; } \\
\text { knowledge of business correspondence; } \\
\text { knowledge of professional terminology. }\end{array}$ \\
\hline Practical and technological & $\begin{array}{l}\text { Personal and practical; } \\
\text { educational; } \\
\text { technological. }\end{array}$ \\
\hline
\end{tabular}

\section{Results}

Ascertaining experiment was conducted to solve the following problems: to find out the attitudes of teachers and students to multimedia application in the classroom; to check the formation of skills in different kinds of speaking activity and grammatical and lexical knowledge of students; to identify the main motives of undergraduates to study a foreign language; to determine the ability of undergraduates for self-esteem activities; to check the students' orientation for a certain type of engineering; to analyse the ability of students to use multimedia in practice. The outlined problems were solved by using the methods like questionnaires, teacher observations, quantitative and qualitative methods of processing the data, etc. The analysis of the results confirm that students have high motivation for learning a foreign language, express the ability to analyse and evaluate their activities (using of self-assessment sheet), define focus on a certain type of engineering (method of O. Hodlinik).

The purpose of the formative experiment is the implementation of the proposed model of foreign language competence in the experimental group training by means of blended learning that is a combination of traditional teaching with elements of distance learning. We used different multimedia technologies in teaching students of the experimental group. Students' individual work was carried out with the use of distance course "English for Mechanical Engineering students".

The formative experiment revealed positive changes in the levels of forming foreign language competence of the experimental group compared with the control one. It was found that the number of students in EG with high levels of motivation, reflective, cognitive activity, practical and technological criteria increased. Comparative analysis of the experimental results showed the increasing of levels of formation of foreign language competence of Master's students after the formative experiment, while the results of the control group didn't increase.

Table 2

Levels of formation of foreign language competence of Master's students after the formative experiment, \%

\begin{tabular}{|c|c|c|c|c|c|c|c|c|}
\hline \multirow{3}{*}{ Criteria } & \multicolumn{8}{|c|}{ Levels } \\
\hline & \multicolumn{2}{|c|}{ High } & \multicolumn{2}{|c|}{ Sufficient } & \multicolumn{2}{|c|}{ Average } & \multicolumn{2}{|c|}{ Low } \\
\hline & EG & $\mathrm{CG}$ & EG & $\mathrm{CG}$ & EG & $\mathrm{CG}$ & EG & CG \\
\hline Motivation & 46,5 & 27,8 & 34,4 & 35,4 & 13,5 & 23,3 & 5,6 & 13,5 \\
\hline Reflexive & 50,3 & 29,8 & 31,4 & 26,1 & 15,2 & 36,5 & 3,1 & 7,6 \\
\hline Cognitive activity & 34,6 & 15,1 & 39,7 & 36,4 & 21,3 & 40,2 & 4,4 & 8,3 \\
\hline Practical and technological & 51,8 & 13,2 & 25,1 & 19,9 & 18,7 & 49,3 & 4,4 & $\overline{17,6}$ \\
\hline
\end{tabular}


Therefore, the high level of formation of motivational criterion is $39.2 \%$, sufficient $-31.8 \%$ in EG and students of control group have $31.1 \%$ and $33.5 \%$ respectively.

$39.7 \%$ of undergraduates of the experimental group show the high level of formation of reflective criterion, sufficient $-29 \%$, average $-26.4 \%, 4.5 \%$ - low level. The results of the reflexive criterion in CG are: high $-31.8 \%$, sufficient $-23.9 \%$, average $-38 \%$, low $-6.2 \%$. The indicators of the cognitive activity criterion of the control group at a high level are $15.1 \%$.

\section{Discussion}

In order to verify the results of the research, the calculations were performed with the methods of mathematical statistics using non-parametric test of Pearson criterion $\chi^{2}$ and the test of Cramer-Welch. These methods helped to find out that there is a significant difference between the experimental and control groups after the introduction of multimedia in the learning process. The effectiveness of the experimental method is confirmed by selected criteria with a level of reliability not less than $95 \%$. It demonstrates the effectiveness of using multimedia technologies and distance learning course "English for Mechanical Engineering students".

The scientific problem is solved in our research that is developing, scientific substantiation and experimental verification of the model of the formation of foreign language competence of Master's students in Mechanical Engineering by means of multimedia. The testing methodology of formation of foreign language competence of students in Mechanical Engineering by means of multimedia is improved.

The concept of "foreign language competence" is determined. Based on the analysis of sources it is defined that foreign language competence covers a set of linguistic, sociolinguistic and pragmatic competence. Linguistic competence covers lexical, grammatical, semantic, phonological, orthographic and pronouncing competence. Sociolinguistic competence includes knowledge and skills necessary to carry out the social dimension of language use. Pragmatic competence is knowledge of the principles of the structure and use of statements.

The obtained results confirmed the correctness of the hypothesis, according to which the effectiveness of professional training of engineering students enhances if the formation of foreign language competence is carried out with the use of multimedia and under certain pedagogical conditions.

Using multimedia is an important part of educational environment because it improves independent extracurricular work of students. The development of multimedia technology meets the demands for new ways of teaching language (Shi, 2017, p. 29). Various educational systems where teachers can create distance learning courses according to the curriculum provide more opportunities for learning. Using multimedia increases the level of foreign language knowledge, develops students' interest for studying languages, intensifies and diversifies the independent work of students.

Supporting the teaching process with appropriate e-learning techniques and web tools influences positively the development of language skills, and consequently favours the development of the key competence of communicating in foreign languages (Kalamarz, 2014, p. 93).

Students should know a foreign language at a sufficient level for social communication, the performance of professional tasks and communication in an academic environment (Nikolaieva, 2003). The professional focus is the basis for foreign language teaching of engineering students.

Leading countries are paying due attention to the use of modern technology. Blended learning, distance learning, online universities, use of multimedia technologies (Jung \& Lim, 2014) are becoming increasingly popular. The number of universities that use distance learning technologies effectively increases. The formation of foreign language competence in Europe is based on the major teaching documents of the Council of Education, Project Tuning, the European Language Portfolio, the European survey on language competences.

Current conditions of society change requirements for professional training of undergraduates. Ukraine aspires to join the European Union that's why we should focus on the studying of global trends in general training and language policy.

In our study, we define that knowledge of native and foreign languages is an integral part of the professional training of future engineers. Researchers dealing with the issues of formation of foreign language competence of future professionals in different areas of training distinguish its various components and criteria. By carrying out a systematic analysis of research, we examine that the formation of foreign language competence is a part of the professional competence of future professionals.

Accelerating the pace of technological development of industry, modern conditions of economic globalisation, informatisation of education require new approaches to the teaching of future engineers. It should be understood that the engineering industry requires highly skilled specialists with knowledge of professional disciplines, new technologies, and foreign languages. It is necessary to look for new approaches 
to learning/teaching of these subjects, so the use of multimedia for training future engineers can become a key combination of new technologies, professional informative fullness, and effective learning environment.

\section{Conclusions}

The obtained data confirm the efficiency of the model of forming foreign language competence. The testing methodology of formation of foreign language competence of Master's students in Mechanical Engineering by means of multimedia is improved: its criteria, indicators, and levels of development are identified. The concept of "foreign language competence" is defined. The model of the formation of foreign language competence of Master's students in Mechanical Engineering is elaborated.

Taking into account the main results of the research it is possible to give practical guidance on the following levels:

- Organisational and administrative (creation of the training programs for teaching staff that will provide development of distance learning);

- Organisational and methodical (the improvement of curricula through regular use of multimedia in the educational process);

- Practical (using multimedia technologies for teaching engineering students).

The problem of formation foreign language competence is complex and multifaceted. The research could not develop all aspects of the formation of foreign language competence of future professionals. The suggestions for future research are:

- to develop special courses for learning teachers to use multimedia in the educational process;

- to research the use of multimedia in the process of foreign language self-study;

- to develop specialised software and create the educational facilities for students on its basis.

The received results confirm the correctness of the hypothesis, according to which the effectiveness of teaching the engineering students enhances if the formation of foreign language competence is carried out with the use of multimedia and implemented in the case of providing the appropriate educational environment.

\section{References:}

Ashton, K. (2014). Reflections on international comparative education survey methodology: a case study of the European Survey on Language Competences. A Journal of Comparative and International Education, 3, $414-434$. https://doi.org/10.1080/03057925.2014.963512

European Glossary on Education. Examinations, Qualifications and Titles (2004). Brussels: Eurydice.

Feschuk, A. (2016). Conceptual basis of professionally oriented foreign language training of future specialists in applied mechanics. Advanced Education, 5, 42-48. https://doi.org/10.20535/2410-8286.62669

First European Survey on Language Competences. Final Report (2004). Retrieved May 10, 2017 from: http://ec.europa.eu/languages/library/studies/executive-summary-eslc_en.pdf

Jung, B. \& Lim, S. (2014). Building E-learning apps with multimedia contents for learning language variations. International Journal of Multimedia and Ubiquitous Engineering, 9 (11), 339-348. https://doi.org/10.14257/ijmue.2014.9.11.33

Kalamarz, R. (2014). Blending foreign language learning with key competences. Does e-learning do the trick? Int. J. Cont. Engineering Education and Life-Long Learning, 24 (1), 97-111. https://doi.org/10.1504/ijceell.2014.059336

Shi, X. (2017). Application of multimedia technology in vocabulary learning for engineering students. International Journal of Emerging Technologies in Learning, 1, 21-31. https://doi.org/10.3991/ijet.v12i01.6153

The European Qualifications Framework for Lifelong Learning (2008). Luxembourg: Office for Official Publications of the European Communities.

Tuning Education Structures in Europe. 2nd Edition (2008). Retrieved May 10, 2017 from http://www.unideusto.org/tuningeu

Babyn, I. I., Boliubash, Ya. Ya. \& Harmash, A. A. (2011). Natsionalnyi osvitnii hlosarii: vyshcha osvita [Glossary of National Education, Higher Education]. Kyiv: Pleiady.

Bakayeva, H.Ye. \& Borysenko, O.A. (2005). English for Specific Purposes. National Curriculum for Universities. Kyiv: Lenvit.

Holovei L. \& Rybalko Ye. (2002). Praktikum po vozrastnoy psikhologii [Workshop on age-related psychology]. SPb, Russia.

Honcharenko, S. U. (2011). Ukrainskyi pedahohichnyi entsyklopedychnyi slovnyk [Ukrainian Pedagogical Encyclopedic Dictionary]. Rivne: Volynski oberehy.

Ilin, Ye. P. (2003). Motivatsiya i motivy [Motivation and motives]. Saint Petersburg, Russia: Piter.

Nikolaieva, S. Yu. (Ed.) (2003). Zahalnoievropeiski Rekomendatsii z movnoi osvity: vyvchennia, vykladannia, otsiniuvannia [Common European Framework of Reference for Languages: Learning, Teaching, Assessment]. Kyiv, Ukraine: Lenvit.

Stavytska, I.V. (2015). Formuvannia inshomovnoi kompetentnosti mahistrantiv mashynobudivnykh spetsialnostei zasobamy multymedia [The Formation of Foreign Language Competence of Master's Students in Mechanical Engineering by Means of Multimedia]. Unpublished PhD dissertation Institute of Higher Education of NAPS of Ukraine, Kyiv, Ukraine.

Zakon Ukrainy pro vyshchu osvitu №1556-VII (July 1, 2014) [The Law of Ukraine on Higher Education №1556-VII]. Retrieved May 10, 2017from http://zakon4.rada.gov.ua/laws/show/1556-18 